\title{
Effect of Mineral Organic Fertilization and Inoculation with Phosphate- Solubilizing Microorganisms on Growth and Yield of Sorghum (Sorghum bicolor L.)
}

\author{
Radwan, F. I., M. A. Gomaa, E. E. Kandil and I. A. Mohamed \\ Plant Production Department, Faculty of Agriculture (Saba Basha), Alexandria \\ University, Egypt
}

\begin{abstract}
Two field experiments were carried out at the Experimental Farm of the Faculty of Agriculture (Saba Basha), Alexandria University, at Abees region, Alexandria, Egypt during the two successive growing seasons of 2012 and 2013 to study the effect of mineral- organic N- fertilization and inoculation with phosphate solubilizing microorganisms on growth and yield of sorghum (Sorghum bicolor L., Cv. Dorado). The applied experimental design was split plot with three replicates. The main plots were conducted for the three mineral- organic manure fertilization $(100 \% \mathrm{~N}, 75 \% \mathrm{~N}+25 \%$ organic and $50 \% \mathrm{~N}+50 \%$ organic), while the uninoculation $+100 \% \mathrm{P}$, phosphorein $+75 \% \mathrm{P}, \mathrm{A}-$ Mycorrhizal $+75 \% \mathrm{P}$ and phosphorein $+\mathrm{A}$ - Mycorrhizal $+75 \% \mathrm{P})$, which were arranged in the subplots. The main results could be summarized as follows: (1) The mineral- organic at $(50 \% \mathrm{~N}+50 \%$ organic), gave the highest mean values of all studied characters, also (2) The mixed biofertilizer inoculation (A- Mycorrhizal + Phosphorein) $+75 \% \mathrm{P}$ was the best treatment to obtain the highest mean values of plant height leaf area index, stalk diameter, no. of branches/head, Total chlorophyll, grain yield, yield components $\mathrm{N}, \mathrm{P}$ and $\mathrm{K} \%$. However, all traits under this study increased, significantly, due to inoculation treatments over "uninoculation $+100 \%$ P". The investigation suggests the need to more studies concerning the effect of biofertilizers and their interaction, as well as applying micronutrients on sorghum plant under different environments using different types of soil to reach the optimum combination to achieve the highest sorghum yield and its quality.
\end{abstract}

Keywords: Sorghum, mineral, organic, biofertilization, growth, yield, chemical composition

\section{INTRODUCTION}

Sorghum (Sorghum bicolor, L. Moench) belongs to the family Poaceae, including both wild and cultivated sorghum. Sorghum is the fifth important crop among the cereals in the world following rice, wheat, maize and barley in total area planted and production (Musa et al., 2012). Sorghum is the principal cereal that forms an important staple diet throughout the semiarid Asian and African regions (Ahmed et al., 2000).

However, fertilizer management is one of the most important factors in successful cultivation of sorghum plants. Fertilizers can affect the yielding, quality and quantity of plant indexes (El- Zeny, 2004). For instance, organic agriculture is a production management system that aims to promote and enhance ecosystem health, including biological cycles and soil biological activity. It is based on minimizing the use of external inputs, and represents a deliberate attempt to make the best use of local natural resources (Hag Ahmed et al., 2007).

Furthermore, biofertilization is one of the most important factors used to produce product free from mineral contamination. On the other hand, the intensive use of chemical fertilizer (in spite of the importance of N, P in metabolic processed), causes environmental pollution problems, and its high rates lead to decrease in the potential activity of micro flora and the mobility of organic matters. Hence the attention has been, focused on the researches of bio- fertilizers to replace the chemical fertilizers. However, biofertilizers play vital role for increasing the number of microorganisms and accelerate certain microbial process in the rizosphere of 
inoculated soil pf plants which can change the available forms and nutrients into plants (Mitkess et al., 1996; Ali et al., 2001; Saini et al., 2004 and Musa et al., 2012).

There were significant differences of growth characters, yield and its components except specific leaf area and harvest index obtained when plant were treated with bio-fertilizer. the combined inoculation with Azotobacter vinelandlii and Pseudomonas fluorescens surpassed the single inoculation either in presence of full or double full dose of organic manure in all characters but the positive control of the recommended doses of NPK recorded the highest significant values in all growth characters at all tested plant ages and yield and its components, while the combined inoculation treatment in presence of either full or double full organic matter dose came in the second order (Ahmed et al., 2010).

The use of phosphate solubilizing bacteria as inoculants simultaneously increases $P$ uptake by the plant and crop yield. Strains from the genera Pseudomonas, Bacillus and Rhizobium are among the most powerful phosphate solubilizers. The principal mechanism for mineral phosphate solubilization is the production of organic acids, and acid phosphatases play a major role in the mineralization of organic phosphorous in soil. Several phosphatase-encoding genes have been cloned and characterized and a few genes involved in mineral phosphate solubilization have been isolated. Therefore, genetic manipulation of phosphatesolubilizing bacteria to improve their ability to improve plant growth may include cloning genes involved in both mineral and organic phosphate solubilization, followed by their expression in selected rhizobacterial strains (Rodríguez and Fraga, 1999).

Therefore, the aim of this study is to study the effect of mineral- organic fertilization and inoculation with phosphate solubilizing microorganisms on growth and yield of sorghum (Sorghum bicolor, L. Moench).

\section{MATERIALS AND METHODS}

Two field experiments were carried out at the Experimental Farm of the Faculty of Agriculture (Saba Basha), Alexandria University, at Abbes region, Alexandria, Egypt during two successive cropping seasons of 2012 and 2013. The applied experimental design was split plot with three replicates. The main plots were allocated for three mineral- organic fertilizers (FYM) of nitrogen (100\% N (80 kg $\mathrm{N} /$ fed.), $75 \% \mathrm{~N}+25 \%$ organic and $50 \% \mathrm{~N}+50 \%$ organic manure), the sub- plots were occupied by the following four treatment of $\mathrm{P}$ - biofertilizers (uninoculation $+100 \%$ $\mathrm{P}$, Phosphorein $+75 \% \mathrm{P}$, Mycorrhizal $+75 \% \mathrm{P}$ and mixture (Mycorrhizal + Phosphorein $+75 \%$ P).

Chemical and physical analysis of the experimental soil sites $(0$ to $30 \mathrm{~cm})$ are shown in Table (1), according to the method reported by Page et al., (1982). The chemical characteristics of compost manure composition are given in Table (2).

The sub plots consisted of 5 ridges 3.5 meters in length, $60 \mathrm{~cm}$ in width and 20 $\mathrm{cm}$ between hills. Nitrogen fertilizer was applied at rate of $80 \mathrm{~kg} \mathrm{~N} / \mathrm{fed}$., $(100 \% \mathrm{~N})$ from urea fertilizer $(46 \% \mathrm{~N}) 60 \mathrm{~kg} \mathrm{~N} / \mathrm{fed}$., $(75 \% \mathrm{~N})$ and $40 \mathrm{~kg} \mathrm{~N} / \mathrm{fed}$., $(50 \% \mathrm{~N})$ in two equal doses. The first one applied just before the first irrigation and after thinning and the second one applied just before the second irrigation. Phosphorus fertilizer was applied before planting as Calcium- super phosphate $\left(15.5 \% \mathrm{P}_{2} \mathrm{O}_{5}\right)$ at the rate of 150 $\mathrm{kg}$. Potassium sulphate $\left(48 \% \mathrm{~K}_{2} \mathrm{O}\right)$, was added before the first irrigation at rate of 50 $\mathrm{kg} \mathrm{K}{ }_{2} \mathrm{O} / \mathrm{fed}$. 
Sowing (Sorghum bicolor L., cv. Dorado) was done on $18^{\text {th }}$ and $20^{\text {th }}$ of June in 2012 and 2013 seasons, respectively. The preceding crop was wheat in the first season and Egyptian clover in the second season.

The seeds inoculation of biofertilizers (Phosphorein) with each product individually using a sticking substance (Arabic gum 5\%) just before planting. Inoculation of A-mycorrhizal fungi for sorghum with fungi (Glomus macrarpium) strain from plant production Dept. (Saba Basha). Alex. Univ., at a rate of $250 \mathrm{ml}$ of infected roots and was mixed with seeds.

Harvesting time was in $20^{\text {th }}$ and $22^{\text {th }}$ of October 2012 and 2013 seasons, respectively.

The following data were recorded in the both seasons.

\section{A- Growth characters}

Plant height $(\mathrm{cm})$, leaf area index $(\mathrm{LAl})$, stalk diameter $(\mathrm{cm})$, and number of branches/head according to Watson (1952).

Total chlorophyll was determined by digital apparatus (SPAD-502) according Monje and Bugbee (1992) and Coste et al. (2010) who suggested this equation to transferred SPAD units to $\mathrm{mg} / \mathrm{m}^{2}$.

$Y=1.034+0.308 * X+0.11 * X^{2}$

where: $X=S P A D$ units

\section{B- Yield and its components}

Panicle length $(\mathrm{cm})$, Panicle weight $(\mathrm{g})$, Panicle grain weight $(\mathrm{g})$, 1000- grain weight (g), grain yield (tons/fed.), straw yield (tons/fed.), and biological yield (tons/fed).

\section{C- Grain chemical composition}

Grains digested with $\mathrm{H}_{2} \mathrm{SO}_{4}-\mathrm{H}_{2} \mathrm{O}_{2}$ mixture (Lowther, 1980) and the following determination were carried out in the digested solution to determine the following:

1- Total $\mathrm{N}$ in grains was determined calorimetrically by Nessler's method (Champan and Pratt, 1978).

2- Total $P$ in grain was determined using vanado- molybdate yellow method (Jakson, 1973).

3- Total $\mathrm{K}$ in grains was determined using the Flame Spectrophotometer.

The obtained data were statistically analyzed using ANOVA and L.S.D. values were calculated to test the difference between the studied treatments according to Gomez and Gomez (1984). 
Table (1). Some physical and chemical properties of the experimental soil in 2012 and 2013 season.

\section{Soil properties}

\begin{tabular}{|c|c|c|}
\hline \multirow{3}{*}{ A-Particle size distribution \%: } & \multicolumn{2}{|c|}{ Season } \\
\hline & 2012 & 2013 \\
\hline & 38 & 37 \\
\hline Silt & 32 & 33 \\
\hline Clay & 30 & 30 \\
\hline Soil texture & Clay loam & Clay loam \\
\hline B-Chemical properties: & & \\
\hline $\mathrm{pH}(1: 1) \quad$ & 8.20 & 8.31 \\
\hline $\begin{array}{l}\mathrm{EC}(1: 1), \mathrm{dS} / \mathrm{m} \\
\text { 1- Soluble cations }(1: 2)(\mathrm{cmo} 1 / \mathrm{kg}\end{array}$ & 3.80 & 3.70 \\
\hline $\begin{array}{l}\text { soil) } \\
\mathrm{K}^{+}\end{array}$ & 1.52 & 1.54 \\
\hline $\mathrm{Ca}^{++}$ & 9.4 & 8.7 \\
\hline $\mathrm{Mg}^{++}$ & $\begin{array}{r}18.3 \\
1350\end{array}$ & $\begin{array}{l}18.5 \\
138\end{array}$ \\
\hline $\begin{array}{l}\mathrm{Na}^{+} \\
\text {2- Soluble anions }(1: 2)(\mathrm{cmo} 1 / \mathrm{kg}\end{array}$ & 13.50 & \\
\hline $\begin{array}{l}\text { soil) } \\
\mathrm{CO}_{3}^{-}+\mathrm{HCO}_{3}^{-}\end{array}$ & $\begin{array}{l}2.90 \\
20.4\end{array}$ & $\begin{array}{l}2.80 \\
19.80\end{array}$ \\
\hline $\mathrm{SO}_{4}^{-}$ & 12.50 & 12.60 \\
\hline Calcium carbonate $\%$ & 6.50 & 7.00 \\
\hline Total nitrogen \% & 1.00 & 0.91 \\
\hline Available P (mg/kg) & 3.70 & 3.55 \\
\hline Organic matter \% & 1.41 & 1.40 \\
\hline
\end{tabular}

Table (2). Analysis of the applied organic manure (Farmyard manure) in 2012 and 2013 seasons.

\begin{tabular}{l|c|c}
\hline \multicolumn{3}{c}{$\begin{array}{c}\text { Farmyard manure composition } \\
\text { (FYM) }\end{array}$} \\
\hline \multicolumn{3}{c}{ Season } \\
\hline \multirow{2}{*}{$\mathrm{pH}$} & 2012 & 2013 \\
$\mathrm{~N} \%$ & 7.2 & 7.3 \\
$\mathrm{P}(\%)$ & 1.66 & 1.75 \\
$\mathrm{~K}(\%)$ & 0.70 & 0.67 \\
Organic $(\mathrm{C} \%)$ & 1.50 & 1.60 \\
$\mathrm{C}: \mathrm{N}$ ratio & 16.3 & 18.3 \\
\hline
\end{tabular}




\section{RESULTS AND DISCUSSION}

\section{A- Growth characters}

The obtained results given in Table (3), showed clearly that mineral nitrogen + organic manure rates exhibited significant effect on all estimated growth traits during both cropping seasons except the stalk diameter in the first season of the study. Notably application mineral nitrogen + organic manure fertilizer rates resulted in a significant effect on plant height, leaf area, number of branches/head, stalk diameter and total chlorophyll. Also, application (50\% mineral $\mathrm{N}+50 \%$ organic manure) gave the highest values of all characters under the study. It could be concluded that the best vegetative growth characters results from the medium percentage compost manure + mineral nitrogen treatment. This finding could be attributed to the mode of action of organic manure in improving the chemical and physical soil characters and increasing nitrogen nutrition as indicated by increased $\mathrm{N}$ concentration in plant tissue (Latif et al., 1998). Also, inoculation with biofertilizer plus $\mathrm{P}$ significantly increased plant height, leaf area index (LAI), stalk diameter $(\mathrm{cm})$, number of branches/head and total chlorophyll during both seasons (Table 3).

The interaction between mineral + organic manure and $\mathrm{P}$ - biofertilization was significant for some growth characters in both seasons Table (3). These results are in harmony with those reported by Agbede et al. (2000), Wang et al. (2003) and Saini et al. (2004). 
Table (3). Effect of mineral nitrogen, organic, P- biofertilization and their interaction on some growth attributes of Sorghum bicolor L., cv. Dorado in 2012 and 2013 seasons

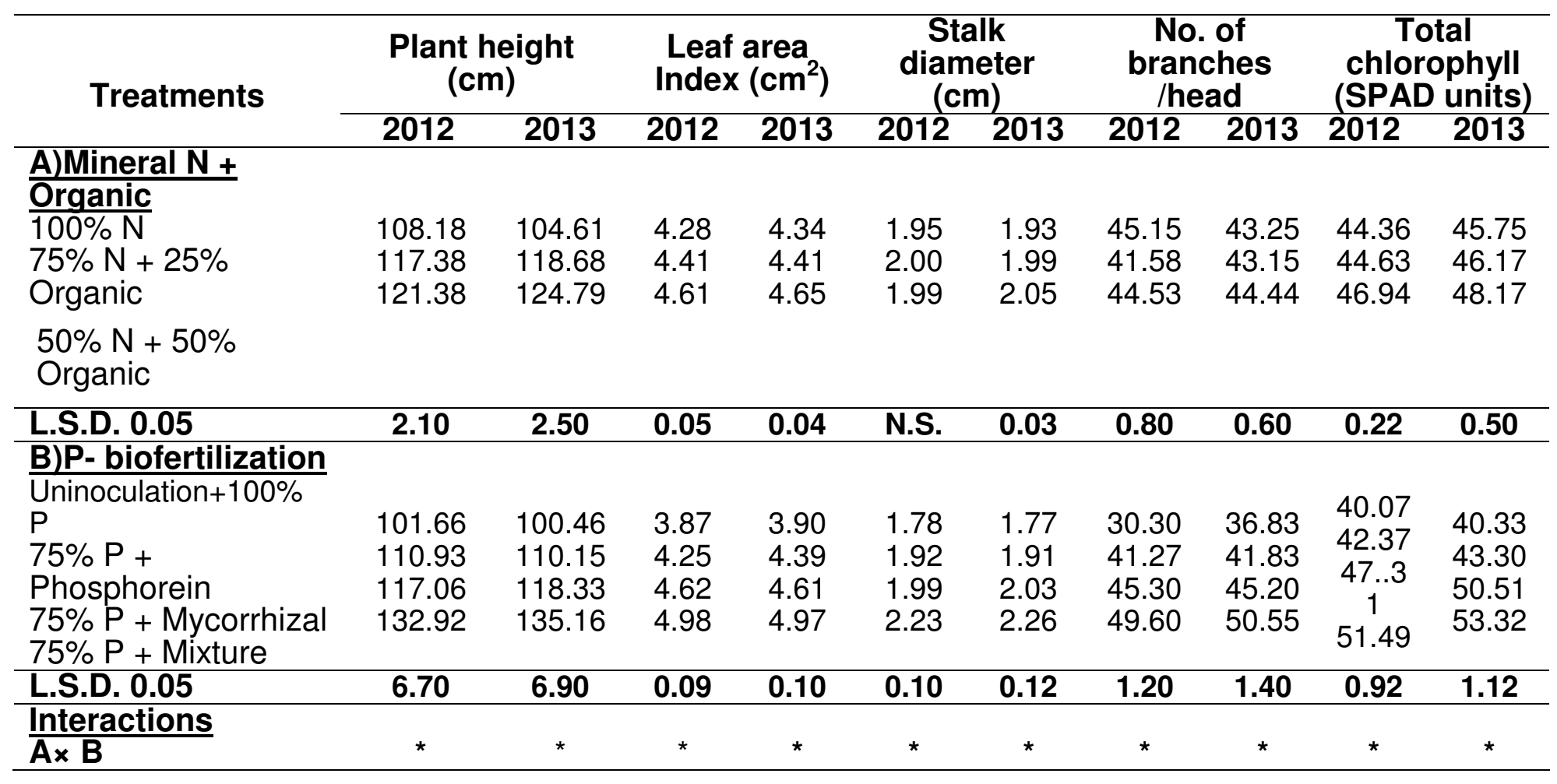

N.S.: not significant difference at 0.05 level of probability.

* : : Significant at 0.05 level of probability. 


\section{B- Yield and its components}

The results recorded in Table (4) showed that yield and its components for both growing seasons were, significantly, affected by "mineral + organic manure rates". Application of (50\% $\mathrm{N}+50 \%$ organic) significantly increased grain yield/fed in both seasons. It could be concluded that the organic manure is beneficial than inorganic fertilizers because the long term use of the combined application of organic and inorganic fertilizers not only increase the soil fertility through increase in nitrogen availability in soil and nitrogen up take by plants but also have an improvement in grain yield. The previous results agree more or less, with the finding of Wang et al. (2003), Materechera and Salagere (2002), and Hag Ahmed et al. (2007).

The mixture biofertilizer plus $P(A$ - Mycorrhizal + Phosphorein) treatment increased the production of sorghum. However, This could be attributes to more adsorption of nutrients, amino acids, cyotkinins, Gebberellins and sugars that come from adding of bacteria's, AM and P. this reflect more growth activity of nitrogenous compounds, assimilation, forming more growth substances, more cell division and elongation in the merstimatic zones and the direct or indirect role of fertilization treatments on metabolism and photosynthetic process of the plants. Similar finding were reported by Hassanein et al. (1997), Ali et al. (2001), Reda et al. (2004) and Saini et al. (2004).

Data in show the effect of $\mathrm{P}$ - biofertilizer inoculation on yield and its components of sorghum characters (Panicle length. Panicle weight, Weight of grain/panicle, 1000- grain weight, grain and straw yields/fed and biological yield/fed) in the two seasons. Yield and its components were improved by the inoculation mixture biofertilizer (A- Mycorrhizal + Phosphorein) $+75 \% \mathrm{P}$ which caused significant increases which may be attributed to the active role of phosphorus dissolving bacteria and fungi and increasing the endogenous photohormones e.g. IAA, GAs and CKs which play important role of formation a big active system and hence increasing the nutrients uptake photosynthesis rate and translocation as well as accumulation within different plants. This result was in accordance with that obtained by Materechera and Salagae (2002), Saini et al. (2004) and Musa et al. (2012).

The interaction between organic manure + mineral and $\mathrm{P}$ - biofertilization was significant for yield and its components in both seasons Table (4).

Figures (1, 2, 3 and 4) conducted that fertilized sorghum plants by $50 \%$ mineral $\mathrm{N}+50 \%$ organic $\mathrm{N}$ with $75 \%$ mineral $\mathrm{P}+$ Phosphorein + Mycorrhizal as mixture recorded the highest mean values of 1000 - grain weight $(\mathrm{g})$ and grain yield (ton/fed). 
Table (4). Effect of mineral nitrogen, organic manure and P- biofertilization on some yield and its components of Sorghum bicolor L., CV. Dorado in 2012 and 2013 seasons

\begin{tabular}{|c|c|c|c|c|c|c|c|c|c|c|c|c|c|c|}
\hline \multirow{2}{*}{ Treatments } & \multicolumn{2}{|c|}{$\begin{array}{c}\text { Panicle length } \\
(\mathrm{cm})\end{array}$} & \multicolumn{2}{|c|}{$\begin{array}{l}\text { Panicle weight } \\
\text { (g) }\end{array}$} & \multicolumn{2}{|c|}{$\begin{array}{l}\text { Weight of grain } \\
\text { Panicle (g) }\end{array}$} & \multicolumn{2}{|c|}{$\begin{array}{l}\text { 1000- grain } \\
\text { weight }(\mathrm{g})\end{array}$} & \multicolumn{2}{|c|}{$\begin{array}{l}\text { Grain yield } \\
\text { (tons/fed) }\end{array}$} & \multicolumn{2}{|c|}{$\begin{array}{c}\text { Straw yield } \\
\text { (tons/fed) }\end{array}$} & \multicolumn{2}{|c|}{$\begin{array}{c}\text { Biological yield } \\
\text { (tons/fed) }\end{array}$} \\
\hline & 2012 & 2013 & 2012 & 2013 & 2012 & 2013 & 2012 & 2013 & 2012 & 2013 & 2012 & 2013 & 2012 & 2013 \\
\hline \multicolumn{15}{|l|}{ A) Mineral N + Organic } \\
\hline $100 \% \mathrm{~N}$ & 28.90 & 29.10 & 94.60 & 91.15 & $42 . .58$ & 40.67 & 38.00 & 39.80 & 1.53 & 1.50 & 1.42 & 1.59 & 2.95 & 3.09 \\
\hline $75 \% N+25 \%$ Organic & 27.60 & 28.40 & 90.90 & 87.75 & 44.50 & 42.67 & 38.80 & 41.90 & 1.68 & 1.52 & 1.86 & 1.96 & 3.54 & 3.46 \\
\hline $50 \% N+50 \%$ Organic & 29.00 & 30.10 & 95.00 & 93.10 & 46.42 & 46.00 & 40.48 & 42.55 & 2.13 & 1.67 & 3.43 & 2.80 & 5.58 & 6.23 \\
\hline L.S.D. 0.05 & 0.25 & 0.35 & 1.30 & 1.40 & 1.20 & 0.95 & 0.80 & 0.92 & 0.10 & 0.08 & 0.37 & 0.35 & 0.40 & 0.36 \\
\hline \multicolumn{15}{|l|}{ B) P- biofertilization } \\
\hline Uninoculation $+100 \%$ & 26.00 & 25.27 & 82.43 & 79.47 & 41.44 & 39.56 & 33.10 & 35.57 & 1.05 & 0.98 & 1.80 & 1.96 & 2.85 & 2.94 \\
\hline $\begin{array}{l}P \\
750 / P\end{array}$ & 27.60 & 28.57 & 91.10 & 88.67 & 43.33 & 41.67 & 38.53 & 39.53 & 1.38 & 1.26 & 2.13 & 2.15 & 3.51 & 4.41 \\
\hline $75 \% \mathrm{P}+$ Phosphorein & 29.13 & 30.90 & $\begin{array}{l}97.90 \\
1025\end{array}$ & 93.33 & 45.33 & 44.89 & 39.87 & 43.87 & 1.95 & 1.53 & 2.44 & 2.26 & 4.39 & 3.79 \\
\hline $\begin{array}{l}75 \% P+\text { Mycorrhizal } \\
75 \% \text { P + Mixture }\end{array}$ & 30.90 & 32.40 & $\begin{array}{c}102.5 \\
7\end{array}$ & 101.20 & 47.55 & 46.33 & 42.90 & 46.63 & 2.77 & 2.48 & 2.54 & 2.21 & 5.37 & 4.69 \\
\hline L.S.D. 0.05 & 0.50 & 0.65 & 1.70 & 1.50 & 1.40 & 1.25 & 1.20 & 1.45 & 0.15 & 0.12 & 0.19 & 0.09 & 0.70 & 0.50 \\
\hline \multicolumn{15}{|l|}{ Interactions } \\
\hline$A \times B$ & * & * & * & * & * & * & * & * & * & * & * & * & * & * \\
\hline
\end{tabular}

* : Significant at 0.05 level of probability. 


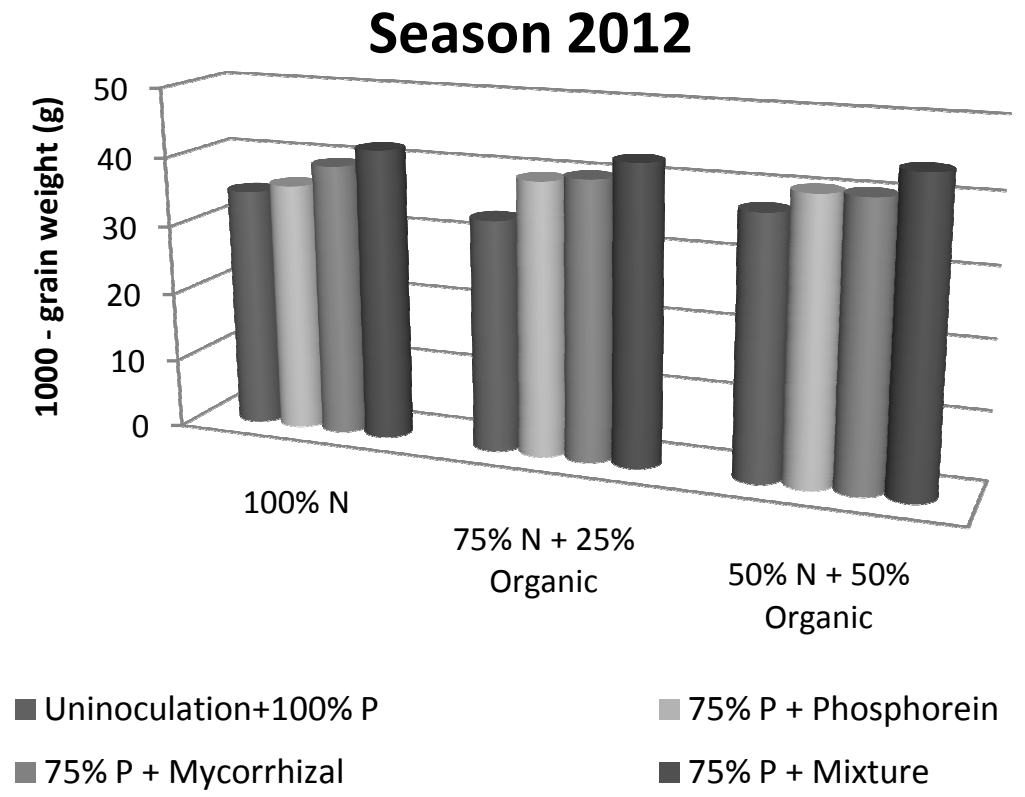

Figure (1). Interaction effect of mineral $\mathrm{N}+$ organic $\mathrm{N}$ and $\mathrm{P}$ - biofertilization on 1000- grain weight in gram of Sorghum bicolor L., Cv. Dorado during season 2012.

\section{Season 2013}

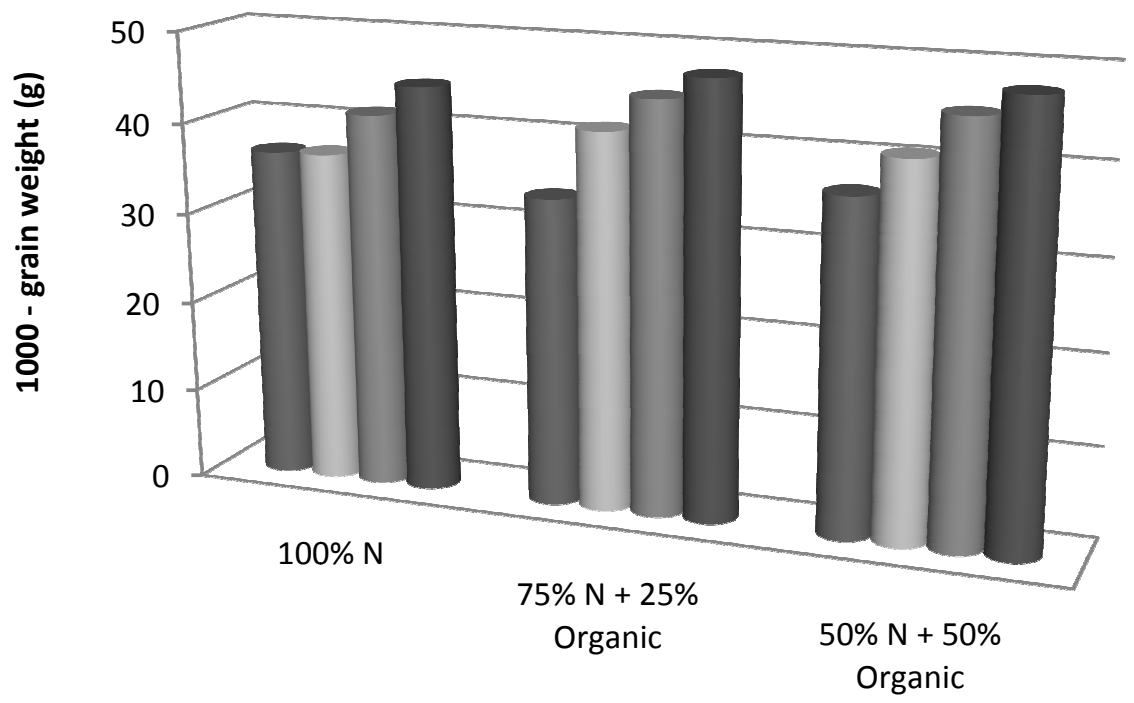

- Uninoculation+100\% P 75\% P + Phosphorein

- 75\% P + Mycorrhizal $\quad$-75\% P + Mixture 
Figure (2). Interaction effect of mineral $\mathrm{N}+$ organic $\mathrm{N}$ and $\mathrm{P}$ - biofertilization on 1000- grain weight in gram of Sorghum bicolor L., cv. Dorado during season 2013.

\section{C- Chemical composition}

Table (5) reflects the data of the effect of mineral + organic manure on $\mathrm{N}$, $\mathrm{P}$ and $\mathrm{K} \%$ of sorghum grains. It is clear from obtained results that the highest mean values of $\mathrm{N}, \mathrm{P}$ and $\mathrm{K} \%$ were resulted from using a mixture of mineral + organic manure during both seasons. Expect $\mathrm{P} \%$ in the first season. However, application (50\% $\mathrm{N}+50 \%$ manure) increased the mean values of $\mathrm{N}$ and $\mathrm{K} \%$ in both growing seasons and $\mathrm{P} \%$ in the second season, but without significant differences between (75\% N + 25\% organic) and (50\% N + 50\% organic) for these characters. The increment in N, P and $\mathrm{K} \%$ of plant grains due to using the treatments of mineral + organic manure may be attributed to the increase in the occupancy root zone of plant as a result of adding mineral + organic manure. Similar results were obtained by Mekki et al. (1999), Agbed et al. (2000) and Wang et al. (2003).

Inoculation of mixture biofertilizer $+\mathrm{P}$ (A- Mycorrhizal + Phosphorein) + $75 \% \mathrm{P}$ caused a significant increase in $\mathrm{N}, \mathrm{P}$ and $\mathrm{K} \%$ in the both seasons than uninoculation $+100 \% \mathrm{P}$. The previous results are compatible with those obtained by Hassanein et al. (1997) and Ali et al. (2001).

The interaction between mineral + organic manure and $\mathrm{P}$ - biofertilization was significant on chemical composition ( $\mathrm{N}, \mathrm{P}$ and $\mathrm{K} \%$ ) in the two growing seasons (Table 5).

Table (5). Macronutrients ( $N, P$ and $\mathrm{K}$ ) percentage and protein \% in grains of Sorghum bicolor L., cv. Dorado as affected by nitrogen levels and biofertilization in 2012 and 2013 seasons

\begin{tabular}{|c|c|c|c|c|c|c|c|c|}
\hline \multirow[t]{3}{*}{ Treatments } & \multicolumn{2}{|c|}{$\mathbf{N} \%$} & \multicolumn{2}{|c|}{$\mathbf{P} \%$} & \multicolumn{2}{|c|}{ K \% } & \multicolumn{2}{|c|}{ Protein \% } \\
\hline & \multicolumn{8}{|c|}{ Season } \\
\hline & 2012 & 2013 & 2012 & 2013 & 2012 & 2013 & 2012 & 2013 \\
\hline \multicolumn{9}{|l|}{ A): Mineral N + Organic: } \\
\hline $100 \% \mathrm{~N}$ & 1.73 & 1.68 & 0.68 & 0.68 & 1.53 & 1.58 & 10.82 & 10.41 \\
\hline $75 \%$ N + $25 \%$ Organic & 1.77 & 1.76 & 0.69 & 0.71 & 1.65 & 1.63 & 11.14 & 11.05 \\
\hline $50 \% N+50 \%$ Organic & 1.79 & 1.77 & 0.71 & 0.72 & 1.64 & 1.66 & 11.05 & 11.01 \\
\hline L.S.D. 0.05 & 0.03 & 0.03 & N.S. & 0.01 & 0.04 & 0.05 & 0.06 & 0.04 \\
\hline \multicolumn{9}{|l|}{ B): P- biofertilization: } \\
\hline Uninoculation+100\% & 1.52 & 1.54 & 0.56 & 0.56 & 1.20 & 1.24 & 9.52 & 9.60 \\
\hline P & 1.71 & 1.66 & 0.65 & 0.65 & 1.58 & 1.58 & 10.65 & 10.37 \\
\hline $75 \%$ P + Phosphorein & 1.80 & 1.78 & 0.73 & 0.75 & 1.72 & 1.72 & 11.25 & 11.10 \\
\hline $\begin{array}{l}75 \% P+\text { Mycorrhizal } \\
75 \% P+\text { Mixture }\end{array}$ & 2.02 & 1.95 & 0.83 & 0.85 & 1.92 & 1.92 & 12.61 & 12.22 \\
\hline L.S.D. 0.05 & 0.05 & 0.04 & 0.05 & 0.06 & 0.07 & 0.07 & 0.71 & 0.75 \\
\hline \multicolumn{9}{|l|}{ Interactions: } \\
\hline$A \times B$ & * & * & * & * & * & * & * & * \\
\hline
\end{tabular}

N.S.: not significant difference at 0.05 level of probability.

* : Significant at 0.05 level of probability. 


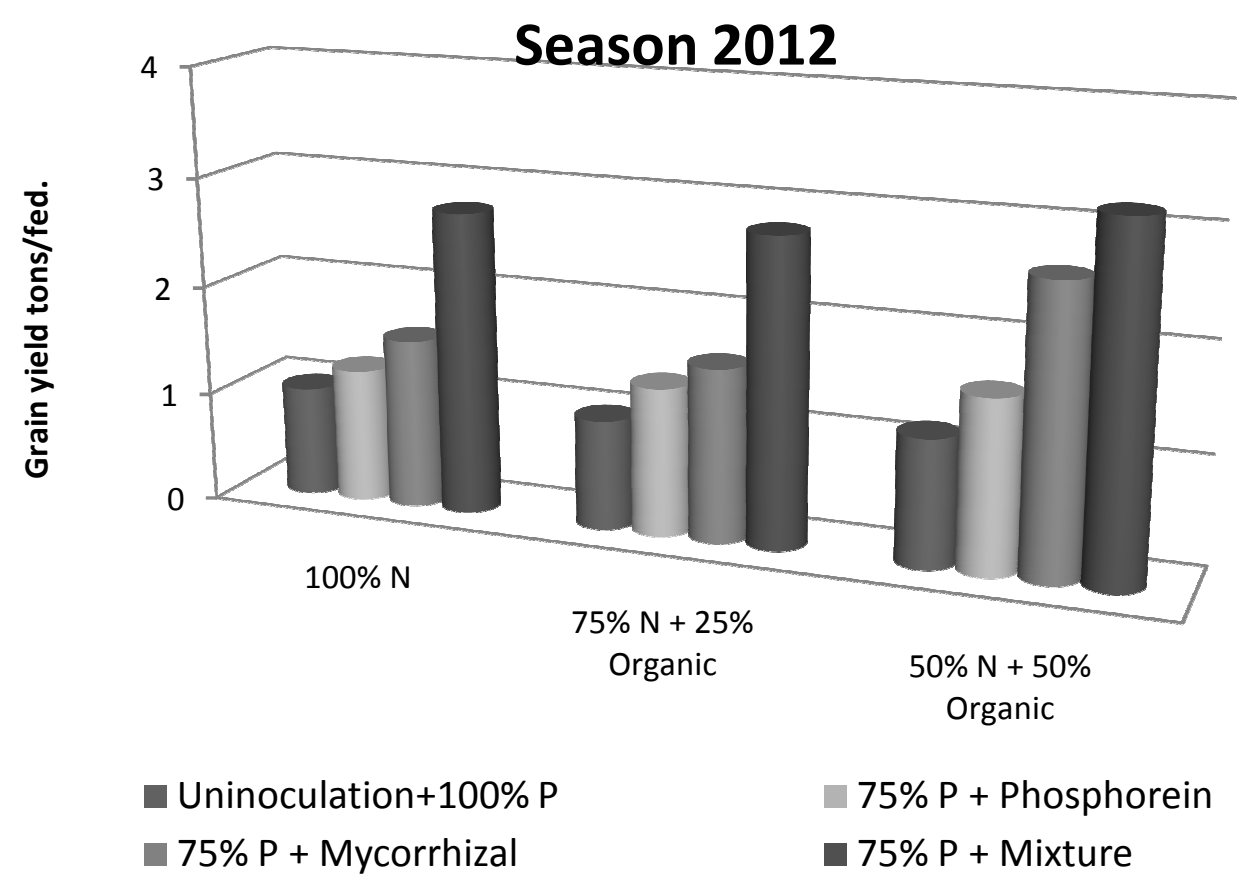

Figure (3). Interaction effect of mineral $\mathrm{N}+$ organic $\mathrm{N}$ and $\mathrm{P}$ - biofertilization on grain yield tons/fed., of Sorghum bicolor L., cv. Dorado during season 2012. 


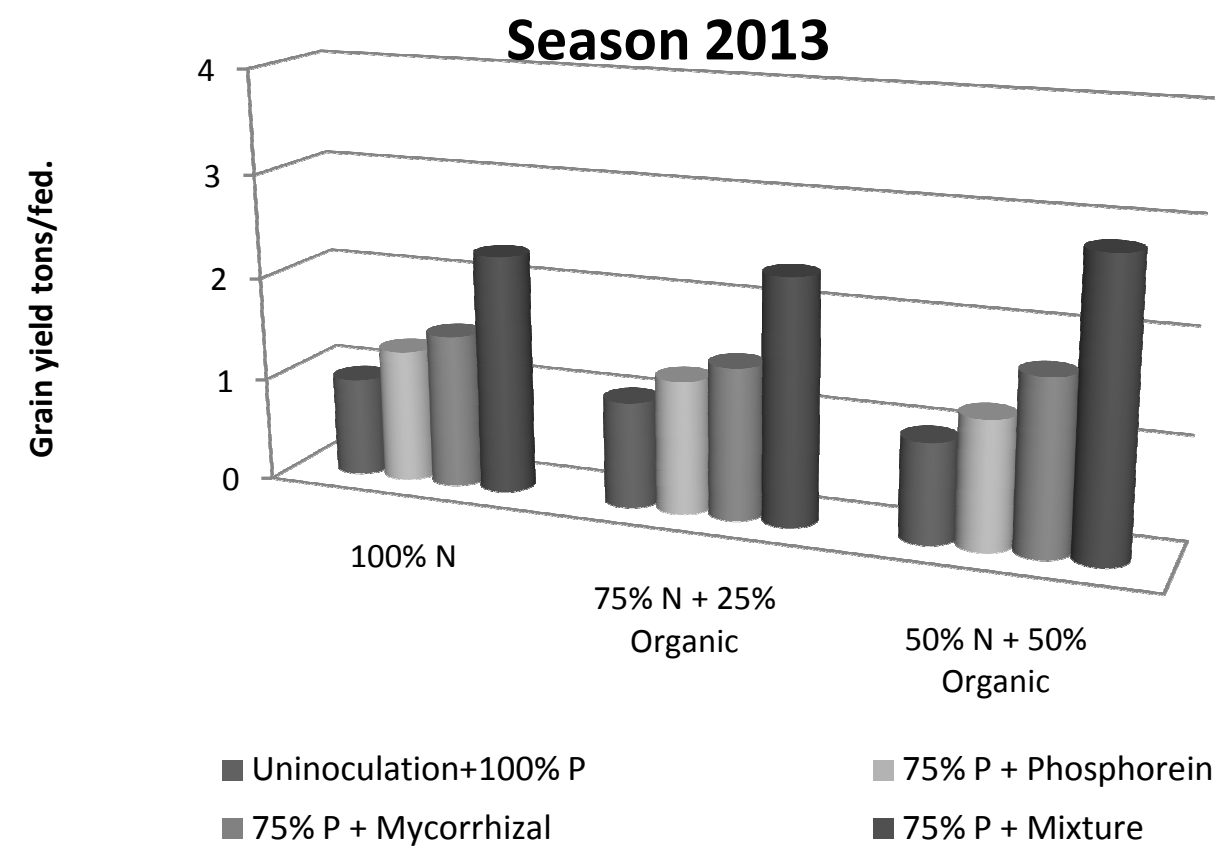

Figure (4). Interaction effect of mineral $\mathrm{N}+$ organic $\mathrm{N}$ and $\mathrm{P}$ - biofertilization on grain yield tons/fed., of Sorghum bicolor L., cv. Dorado during season 2013.

\section{D- Protein \%}

The presented data in Table (5) reported that there was significant difference among treatments; i.e., mineral $\mathrm{N}+$ organic $\mathrm{N}$ and $\mathrm{P}$ - biofertilization. Whereas, the treatment $(75 \% \mathrm{~N}+25 \%$ Organic) recorded the highest mean values for protein \% during two cropping seasons, with no significant difference between this treatment and $(50 \% \mathrm{~N}+50 \%$ Organic N). On the other hand, Pbiofertilization (75\% P + Mixture" Phosphorein+ Mycorrhizal) gave the highest mean values from protein \% during the two growing seasons.

The interaction between mineral + organic manure and P- biofertilization was significant on protein \% during the two growing seasons (Table 5).

Figures (5 and 6) detected that fertilized sorghum plant using $50 \%$ mineral $\mathrm{N}+50 \%$ organic $\mathrm{N}$ with $75 \%$ mineral $\mathrm{P}+$ Phosphorein + Mycorrhizal as mixture gave the highest mean values of protein \% in grains. 


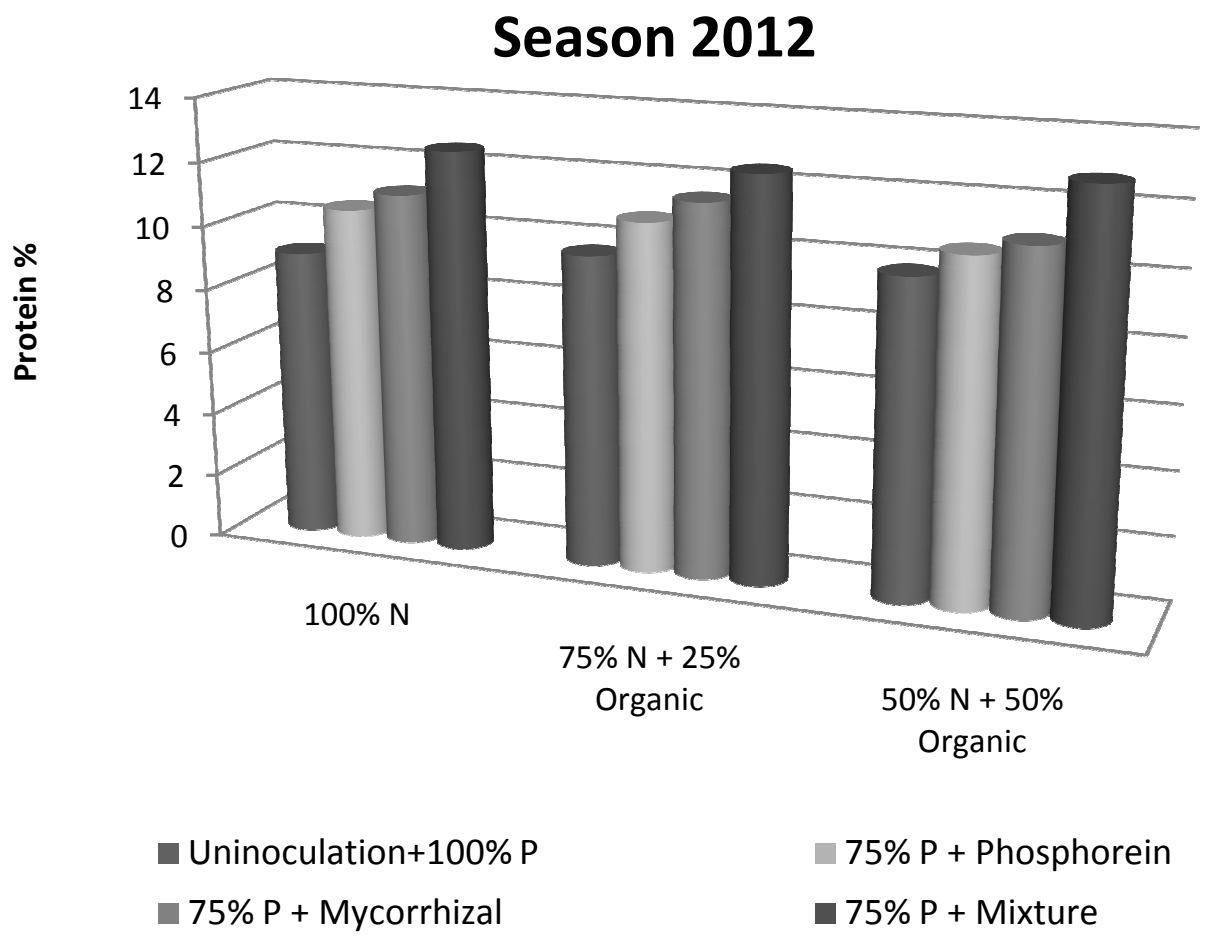

Figure (5). Interaction effect of mineral $\mathrm{N}+$ organic $\mathrm{N}$ and $\mathrm{P}$ - biofertilization on protein percentage of Sorghum bicolor L., Cv. Dorado during season 2012.

\section{Season 2013}

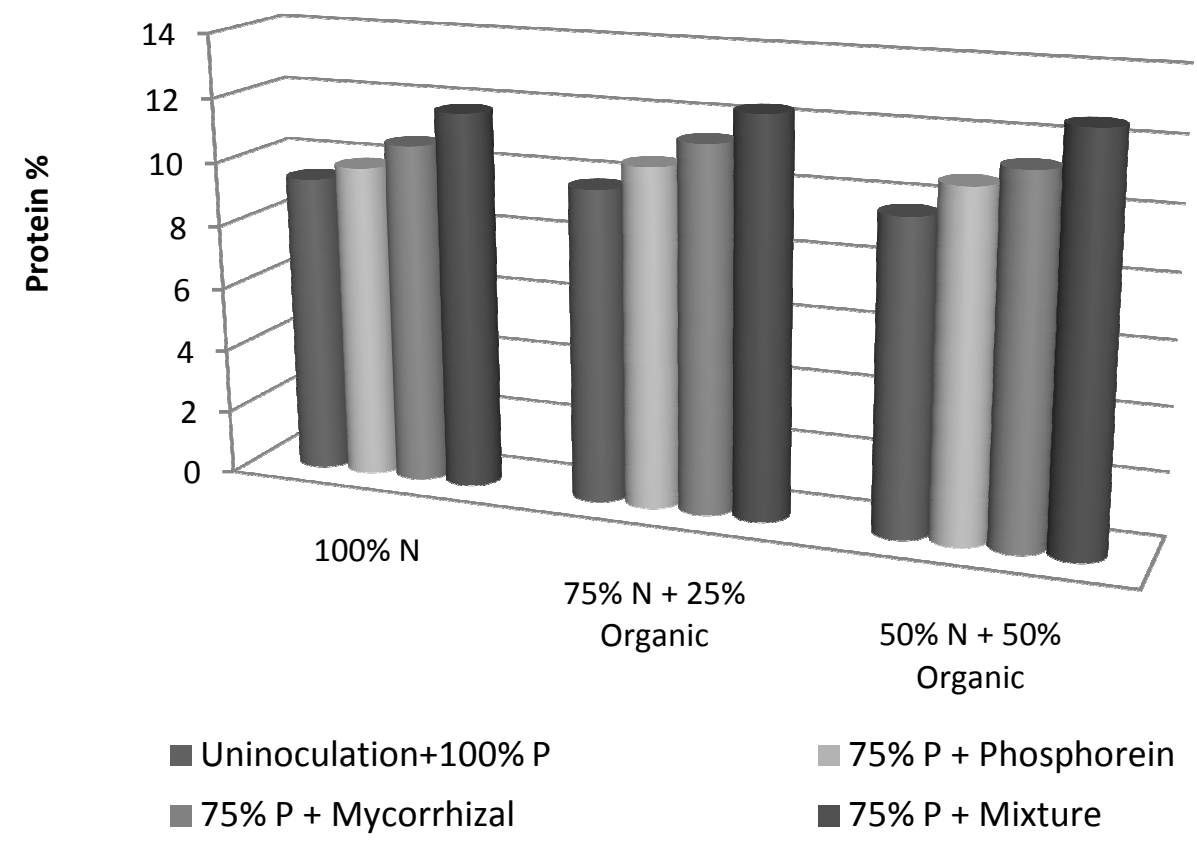


Figure (6). Interaction effect of mineral $\mathrm{N}+\operatorname{organic} \mathrm{N}$ and $\mathrm{P}$ - biofertilization on protein percentage of Sorghum bicolor L., Cv. Dorado during season 2013.

\section{CONCLUSION}

The investigation suggests using $50 \%$ mineral $\mathrm{N}+50 \%$ organic $\mathrm{N}$ with $75 \%$ mineral P + Phosphorein + Mycorrhizal as mixture recorded the highest grain yield and its components of sorghum (Sorghum bicolor L., cv. Dorado) under the condition of this study.

\section{REFERENCES}

Agbede, T. M., S. O. Ojeniyi and A. J. Adeyemd (2000). Effect of poultry manure on soil physical and chemical properties growth and grain yield of sorghum in South West, Nigeria. J. Sustain Agric., 2 (1): $72-77$.

Ahmed, A. G., Salwa Orabi andA.M. Gomaa (2010). Bio-organic farming of grain sorghum and its effect on growth, physiological and yield parameters and antioxidant enzymes activity. Resh. J. Agric. and Biol. Sciences, 6(3): 270-279.

Ahmed, M. M., I. H. Sanders and W. T. Neli (2000). New sorghum and millet cultivar introduction in sub- Saharan. Africa Impacts and Research Agenda. Agric. Systems, 64(1): 55- 56.

Ali, A.H., M.M. AbdEl-Mouty and A.M. Shaheen (2001). Effect of bio nitrogen, organic and inorganic fertilizer on the productivity of garlic plants. Egypt J. Appl. Sci., 16 (3): 173-188.

Chapman, H. D. and P. F. Pratt (1978). Methods of Analysis for soils and waters 2nd Ed. Chapter 7. 150- 161 Univ- Agric Sci. USA.

Coste, S., C. Baraloto, C. Leroy, É. Marcon, A. Renaud, A.D. Richardson, J.C. Roggy, H. Schimann, J. Uddling,B. H'erault.(2010). Assessing foliar chlorophyll contents with the SPAD-502 chlorophyll meter: a calibration test with thirteen tree species of tropical rainforest in French Guiana. Ann. For. Sci. INRA, EDP Sciences, 607. 1:5.

El- Zeny, M. M. (2004). Response of sweet sorghum to appropriate fertilizer regimes Ph. D. Thesis. Agron. Dept. Fac. AgriC. Moshtohor, Zagazig Univ., Egypt.

Gomez, W. K. and A. A. Gomez (1984). Statistical procedures for agricultural research $2^{\text {nd }}$. John Wiley \& Sons. Inc. New York.

Hag- Ahmed, A., U. I. qadir and N. Mahmood (2007). Effect of integrated use of organic and inorganic fertilizers on fadder yield of sorghum (Sorghum bicolor, L.) .Pak. J. Agric. Sci., 44 (3): 415- 419.

Hassanein, M. S., D. M. El- Hariri and M. A. Ahmed (1997). Effect of nitrogen fertilizer levels and bacterium inoculation on yield and its components of maize. J. Agric. Sci. Mansoura Univ., 22 (1): 63- 72.

Jakson, M. I. (1973). Soil chemical analysis Prentice Hall of indea private limited. New Delhe., 498. 
Latif, S. J., E. O. Eweis and A. EL. A. A. Mourad (1998). Response of grain Sorghum hybrid Shandaweel- 2 to plant densities and nitrogen fertilization levels. Egypt. J. Appl. Sci., 13 (9): 64- 71.

Lowther, J. R. (1980). Use of a single $\mathrm{H}_{2} \mathrm{SO}_{4}-\mathrm{H}_{2} \mathrm{O}_{2}$ digests for the analysis of pimus radiate needless. Comm. Soil. Sci., Plant analysis,11: 175- 188.

Materechera, S. A. and A. M. Salagae (2002). Use of partially decomposed cattle and chicken manures amended with wood-ask in two South African arable soils with contrasting texture effect on nutrient uptake, early growth and dry matter yield of maize. Communication in Soil Science and Plant Analysis, 33.1/2. (179-200).

Mekki, B. B., M. M. Selim and M. S. M. Sabe (1999). Utilization of biofertilizers in field crop production 2- effect of organic manure, chemical and biofertilizer on yield and nutrient content of millet grown in a newly reclaimed soil. Egypt. J. Agron, 21: 113- 124.

Mitkees, R. A., Iman M. Sadek. A. M. K. Eissa and S.K. Mahmoud (1996). Use of N2- biofertilizers to decrease $\mathrm{N}_{2}$ - biofertilizers requirements. Nile Valley and Red and Sea Regional Program, Eight. Ann. Coordination Meeting. Egypt 15- 19 Sept. 140- 146.

Monje O.A. and B.Bugbee (1992). Inherent limitations of nondestructive chlorophyll meters - a comparison of 2 types of meters. Hortscience, 27: 69-71.

Musa, E. M., A. E. El- Sidding, A. E. El- Sheikh Isam, A. A. Ahmed and E. E. Babiker (2012). Intercropping sorghum (Sorghum bicolor, L.) and Cowpea (Vigna unguiceilata, L.): Effect of brody rhizobuim inoculation and fertilization on minerals Composition of Sorghum seeds. International Scholarly Res. \& Rev., 1 (3): 138- 146.

Page, A. I., R. H. Miller and D. R. Keeney (1982). Methods of Soil Analysis. Part 2- Chemical and microbiological properties, $2^{\text {nd }}$ Ed. Ass.A. Midison Wise U.S.A.

Reda, M. M. A., S. S. Behair and H. A. Eman (2004). Bio- fertilization as a technique for improving some properties of sandy soil and its productivity. Egypt. J. Appl. Sci., 19 (2B): 766- 772.

Rodríguez, H. and R. Fraga (1999). Phosphate solubilizing bacteria and their role in plant growth promotion. Biotechnology Advances, 17: 319-339.

Saini, V, K., S. C. Bhandari and J. C. Tarfdar (2004). Comparison of crop yield soil microbial and $\mathrm{C}$ : $\mathrm{N}$ and $\mathrm{P}, \mathrm{N}$ fixation nodulation and mycorrhizal infection in inoculated and non- inoculated sorghum and chickpea crops. Field Crops Res. 89: 39- 47.

Wang, T., I. C. Domoney, C. L. Hedley; R. Casey and M. A. Grusak (2003). Can we improve the nutritional quality of legume seeds Plant physiology,131 (3): 886-891.

Watson, D. J. (1952). The physiological basis of variation in yield. Advanced in Agron., 11: 101- 145. 
الملخص العربي

\section{تأثير التسميد المعدني والعضوي والتتليح بالكائنات الاقيقة المذيبة للفوسفات على نمو ومحصول الأرة الرفيعة}

فتحي إبراهيم رضوان ـ محمود عبد العزيز جمعة . عصام إسماعيل قنديل - إبراهيم على محمد

قسم الإنتاج النباتي ـ كلية الزراعة سابا باشا ـ جامعة الإسكندرية ـ مصر

أقيمت تجربتان حقليتان في مزرعة كلية الزراعة سابا باثنا ـ جامعة الإسكندرية ـ بمنطقة أبيس - إسكندرية

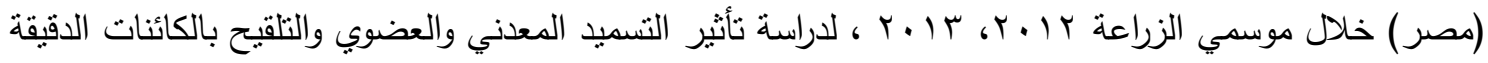
المذيبة للفوسفات على نمو ومحصول الذرة الرفيعة للحبوب (صنف دورادو) . وقد استخدم في هذه التجربة التصميم الإحصائي القطع المنشقة مرة واحدة ولقد خصصت القطع الرئيسية من أجل ب معاملات من مستويات التسميد

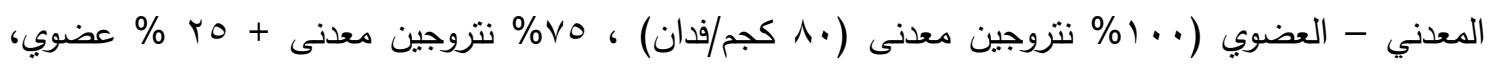

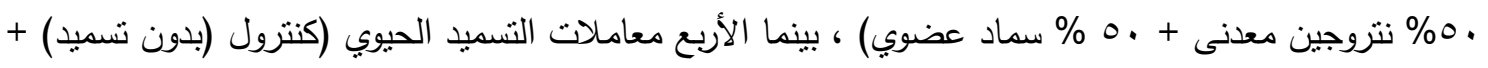

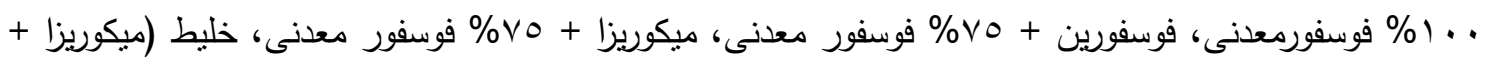
فوسفورين + \%o فوسفور معدنى) والتي كانت فى القطع الثقية.

ويمكن تلخيص أهم النتائج فيما يلي:

أدى إضافة التسميد المعدني والعضوي (•0\% نتروجين معدنى + .0\% عضوي) إلى زيادة واضحة في كل الصفات المدروسة. أظهر التلقيح بمعاملات التسميد الحيوي مضافة إليها التسميد الكيماوي تأثثر معنوياً في كلا الموسمين وبصفة عامة أن التلقيح بخليط (ميكوريزا + فوسفورين + ٪o\% فوسفور معدنى) أعطى أعلى القيم لكل من ارتفاع النبات، دليل المساحة الورقية، قطر الساق، عدد الأفرع/قنديله ، الكلوروفيل الكلي وصفات المحصول ومكوناته والمكونات الكيماوية للنبات ، كذللك النسبة المئوية لكل من ل N, P, K ، \% للبروتين بالحبوب.

ويمكن أن نستخلص من النتائج أن إضافة ـ0 \% نتروجين معدنى + .0 \% سماد الكمبوست العضوي مع التلقيح بخليط (ميكوريزا + فوسفوين + Vo \% فوسفور معدنى) ويمكن أن ينصح به لزيادة إنتاجية الذرة الرفيعة

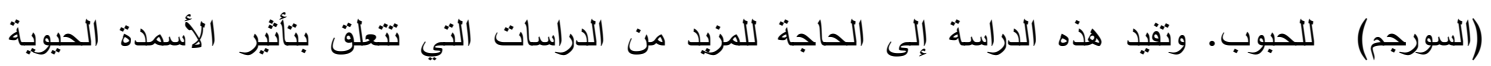
والعضوية مع معدلات من تلك الأسمدة ،وكذلك دراسة التداخل بينها ، هذا بالإضافة إلى دراسة إضافة المغذيات الصغرى للسورجم تحت ظروف بيئية مختلفة مع أنوع مختلفة من الأراضي. 